\title{
$\mathbb{A}$ Economics Bulletin
}

\section{Volume 30, Issue 1}

\section{Capital Structure and Regulation in U.S. Local Telephony: an Exploratory Econometric Study}

\author{
Marcelo Resende \\ Instituto de Economia, Universidade Federal do Rio de Janeiro
}

\begin{abstract}
The paper aims at empirically investigating the relationship between regulation and the capital structure of the regulated firm, A key aspect of the referred relationship pertains a leverage effect according to which debt could be increased as a response to previous physical capital investment with an ultimate goal of inducing higher rates. Theoretical models like Spiegel and Spulber [1997, RAND Journal of Economics] highlight that effect. The present paper considers a panel data set of local exchange carriers-LECs in the U.S. and investigate Granger causality between changes in longterm debt (NDEBT) and gross investment (INV) in physical capital. The evidence accruing from a dynamic panel data estimation indicates an uni-directional causality from INV to NDEBT and therefore is, to a large extent, consistent with a leverage effect and with the notion that the size of the firm's investment project can impose a restriction on the amount of new debt. The result prevails independent of a control variable that indicates the regulatory regime.
\end{abstract}

Financial support from FAPERJ is gratefully acknowledged

Citation: Marcelo Resende, (2010) "Capital Structure and Regulation in U.S. Local Telephony: an Exploratory Econometric Study", Economics Bulletin, Vol. 30 no.1 pp. 392-404.

Submitted: Dec 10 2009. Published: January 28, 2010. 


\section{Introduction}

A relatively small body of literature has emerged in terms of empirical studies on the incentive properties of different regulatory regimes. In the context of telecommunications, salient aspects include the assessment of productive efficiency as given, for example, by Majumdar (1997), Resende (1999, 2000) and Uri (2001) and studies on service-quality that include $\mathrm{Ai}$ and Sappington (2002), Banerjee (2003), and Resende and Façanha (2005). The actual regulatory practice mostly revealed a gradual substitution of traditional rate-of-return regulation by regimes involving earnings sharing or price caps. The evidence, however, is mixed in what concerns the different incentive properties of the different regulatory regimes [see Kridel et al. (1996) and Sappington (2002) for an overview of the related issues and earlier empirical works].

A different regulatory aspect referring to the impact on capital structure has received scarce empirical attention in the literature. Bradley et al. (1984) have obtained evidence that regulated industries would appear among the most leveraged sectors. Moreover, Bortolotti et al. (2008) investigated a panel of publicly traded European utilities and found that firms tended to have a higher leverage if they are privately-controlled and if they are regulated by an independent agency. In addition to the ownership aspect, the authors obtained evidence that leverage has a positive impact on regulated prices. Nevertheless, the literature on the relationship between regulation and capital structure concentrates in the theoretical front, and studies by Spiegel $(1994,1996)$ and Spiegel and Spulber $(1994,1997)$ pinpointed the possible relevance of a leverage effect according to which firm could induce higher rates by the regulator. In fact, by becoming more leveraged the regulated firm can induce a more favorable rate setting by the regulator who wants to avoid risks of bankrupcy following expressive previous investments in physical capital. Philips (1988) suggests that the phenomenon appears to be empirically relevant but a clear quantitative investigation is still lacking in the literature.

The present paper aims at providing an initial exploratory effort in connection to the investigation of the leverage effect. For that purpose, Granger causality tests between changes in debt and investment in physical capital are conducted for a panel of local exchange carriers-LECs.

The paper is organized as follows. The second section discusses some conceptual aspects referring to the relationship between regulation and capital structure and presents the basic aspects of the econometric framework. The third section discusses the construction of the data and presents the empirical results for the dynamic panel data empirical model. The fourth section brings some final comments.

\section{Regulation and Capital Structure}

\section{1- Conceptual aspects}

The strategic interaction between the regulator and the regulated firm is complex in the context of the latter capital structure. A central aspect pertains the relevance of a leverage effect that had already been highlighted in the theoretical literature by Spiegel $(1994,1996)$ and Spiegel and Spulber (1994) in the case of symmetric information between the parts. The logic of the leverage effect is that the regulated firm could have an incentive to become leveraged and ultimately induce a more favorable rate setting by the regulator, whereas the latter would be willing to accomodate to a certain extent to avoid the possibility of bankruptcy by the firm.

The aforementioned strategic relationship becomes even more complex in the presence of asymmetric information between the regulator and the regulated firm. 
Spiegel and Spulber (1997) advance a sequential model that partially builds on Banks (1992) and Besanko and Spulber (1992) that highlights the limited commitment ability by the regulator that is captured by taking the regulated firm as the first mover. The three stages game begins with the regulated firm choosing the capital structure in terms of the mix between debt and equity to outside investors that will provide funds for investment in physical capital. In the second stage, the prices of the firms securities will be defined in the capital market and will also reflect expectations associated to the future regulatory policy. In the third stage, the regulator will set the rates in acordance with some welfare maximization criterion that considers consumer surplus and profits.

In addition to the leverage effect, the asymmetric information context brings a complex signalling problem as there are two receivers (regulator and outside investors) for which the firm has conflicting incentives. In fact, the firm would like to send a positive signal to the capital market so as to indicate low expected costs to the outside investors and good profits prospects but also would be willing to signal high costs to the regulator so as to induce higher rates. Possible equilibria will reflect those various aspects. The present paper intends to conduct an initial empirical investigation on aspects favouring the first aspect of the problem, namely that of the leverage effect, but of course the theoretical literature warrants a far deeper investigation in the future.

\section{2- Econometric framework}

The present application will consider a panel of firms and verify whether there is evidence that new debt is caused by gross investment in physical capital. A dynamic panel data structure will preclude the utilization of traditional panel data estimators given well known biases [for and overview of consistent and efficient estimators for dynamic panel data see Baltagi (2001) and Bond (2002)].

A simple dynamic model for is given by:

$$
y_{i t}=\alpha y_{i, t-1}+\beta x_{i t}+\mu_{i}+v_{i t}
$$

The model could also include time effects $\left(\lambda_{t}\right)$ that would capture non-observed heterogeneities that only depend on the time period and typically are considered by means of period dummy variables. The lagged dependent variable induces significant biases in traditional panel data estimators and therefore Arellano and Bond-AB (1991) have suggested a consistent and efficient estimator for short panels based on the first difference of the dynamic model. The estimator is generalized method of moment estimator that uses orthogonality condition on the appropriate instruments and the error (henceforth GMM-DIF). The first differencing of expression (1) would readily lead to:

$$
\Delta y_{i t}=\alpha \Delta y_{i, t-1}+\beta \Delta x_{i t}+\Delta v_{i t}
$$

The lag structure of the equation in differences will reflect the chosen lag structure of the equation in levels. The first-differencing transformation therefore eliminates the fixed effect. It can be verified that appropriate instruments for $\Delta y_{i, t-1}$, in terms of lagged dependent variable in levels, become increasingly available starting with $\mathrm{y}_{\mathrm{i} 1}$ at $\mathrm{T}=3, \mathrm{y}_{\mathrm{i} 1}$ and $\mathrm{y}_{\mathrm{i} 2}$ at $\mathrm{T}=4$ up to $\mathrm{y}_{\mathrm{i} 1}, \ldots, \mathrm{y}_{\mathrm{i}, \mathrm{T}-2}$ for $\mathrm{T}$. The remaining elements of the instrument matrix will depend on the assumptions regarding additional regressors $\mathrm{x}_{\mathrm{it}}$. In the simplest case where they are assumed to be strictly exogenous (uncorrelated with past, current and future errors) the variables can be readily used as instruments whereas in the case of endogeneity, an instrumenting procedure with lagged variables in levels that is analogous to the previous procedure would be implemented. The validity of the instruments is important for the consistency of the 
GMM-DIF estimator. Sargan's test for overidentifying restrictions in terms of the joint significance of the instruments in excess to the minimum necessary for identification and would be distributed as a chi-square with the number of degrees of freedom given by the difference between the number of instruments and the number of endogenous variables, under the null hypothesis. Additionally, even in the absence of serial correlation for the model in levels, the first-differencing procedure would induce first-order serial correlation but not second-order serial correlation. Tests for $\mathrm{AR}(1)$ and $\mathrm{AR}(2)$ were suggested by $\mathrm{AB}$ and the latter is important to assure adequate properties to the estimator. Under the null hypothesis of no serial correlation, the test statistics would follow a standard normal distribution.

The focus of the paper will be on tests for Granger causality. The concept is largely widespread since Granger (1969). Let $\mathrm{x}$ and $\mathrm{y}$ denote two stationary stochastic processes, $\mathrm{x}$ is said to Granger cause $\mathrm{y}$ if the inclusion of past values of $\mathrm{x}$ help to explain y by reducing the variance of the prediction error, that is:

$$
\sigma^{2}\left(y_{t} \mid y_{t-1}, . . y_{t-p}, x_{t-1, .} \ldots x_{t-p}\right)<\sigma^{2}\left(y_{t} \mid y_{t-1}, . . y_{t-p} .\right)
$$

Applications for time series became routine whereas applications for dynamic panels data are becoming increasingly common as exemplified by Banerjee (2003) in the context of regulation. In operational terms, one runs a regression of $y$ on past values of $\mathrm{y}$ and past values of $\mathrm{x}$, and $\mathrm{x}$ would cause $\mathrm{y}$ if one obtains jointly significant coefficients for the lagged $\mathrm{x}$ variables. A causality in the opposite direction would, of course, be evaluated in terms of the reverse regression and assessment of the joint significance of lagged y variables. In the context of the present GMM-DIF application, Wald type tests will be conducted.

\section{1- Data Sources}

\section{Empirical Analysis}

The paper relies on different data sources. First, the data on debt and physical investment are obtained from the annual report given by the Statistics of Communication Common Carriers from the Federal Communications CommissionFCC. In fact, that is a traditional and comprehensive source for accounting and plant data for U.S. local exchange carriers-LECs. A consistent balanced panel was constructed so as to avoid merging problems. The final sample comprised 31 firms that are listed in the appendix. The data construction can be summarized as follows: . NDEB: defined by the change in long-term debt, where the values were deflated by the telecommunications implicit price deflator [1996=100, provided by the U.S. Bureau of Economic Analysis]. Excluding the possibility of debt renegotiations, the change in long-term debt appears to be a sensible approximation to the change of debt more connected with physical capital changes;

. INV: defined by the change in physical capital as indicated by the change in gross communication plant. In the deflating procedure, an average of the telecommunications implicit price deflator [1996=100, provided by the U.S. Bureau of Economic Analysis] was considered. The averaging process intends to account for the presence of different capital vintages coexisting in a given time. The time horizon for the calculated average was set in 10 years The weighting scheme considers geometrically declining weights given by 
(1- $\left.\delta_{\mathrm{A}}\right)$ where $\delta_{\mathrm{A}}$ stands for the average (across time and firms) of the depreciation rate (depreciation expenses divided by communication plant). The procedure is summarized by the following expression: ${ }^{1}$

$$
\operatorname{ATIMP}_{t}=\frac{\sum_{i=0}^{9}\left(1-\delta_{A}\right)^{i+1} \operatorname{TIMP}_{t-i}}{\sum_{i=0}^{9}\left(1-\delta_{A}\right)^{i+1}}
$$

. REG: indicates the proportion of the firm's activities that is subject to price cap regulation. The state level information on regulatory regimes was obtained from Abel and Clements (1998). In order to obtain firm-level variables in the case of LECs operating in different states, I made use of the number of local loops for the firms at state level as provided by the Monitoring Report-FCC. That information allowed to generate state-level weights. The procedure had been used by Resende and Façanha (2005) and is used here for some additional LECs. The information provided by Abel and Clements (1998) that served as the basis of the construction of REG led to the focus on the sample period of 1989-1998 after constructing the aforementioned variables defined in term of first-differences.

The analysis of the U.S. local telephony provides an important potential for comparing regulatory regimes that are mostly defined at the state level. ${ }^{2}$

In the present application, the possibility of controlling for the regulatory regime can be interesting given that the more strict controls that prevail under rate-of-return could, in principle, induce different impacts on capital structure. The reasons for the chosen sample period

a) Detailed information on regulatory regimes are only available until 1998 as provided by Abel and Clements (1998);

b) The Telecommunications Act of 1996 and the growing penetration of VoIP delineates a more competitive environment a few years after;

c) The contrast between regulatory regimes becomes less evident over time as price-cap regimes gradually prevail;

d) After 1998 the coverage of the referred FCC report displays some reduction as some smaller LECs no longer reported data in that publication and also one observes the decline of total access lines in the case of some LECs what may reflect the possibility that traditional fixed telephony becomes growingly subject of alternative competition

Altogether, the sample period of 1989-1998 appears as especially relevant for establishing suitable controls for the regulatory regime prevailing at the state level.

\section{2- Empirical Results}

Tables 1 and 2 present the results for the two-step GMM-DIF estimation. ${ }^{3}$ The results were obtained with the software DPD 1.21 that runs in the platform Ox 3.0. In order to ascertain desirable properties for the estimator one needs to verify the validity of the chosen instruments in terms of the overidentifying Sargan's test. The test assesses the joint significance of the instruments in excess to the minimum

\footnotetext{
${ }^{1}$ A similar procedure was considered by Resende (1999). However, the focus of the analysis of the present paper is on changes in gross communication plant as one wants to investigate whether changes in debt are induced by changes in physical capital of whatever nature even if it involves replacements associated to depreciation.

2 Previously explored in terms of the construction of a regulatory regime variable as in Resende (1999, 2000) and Resende and Façanha (2005)

${ }^{3}$ Small sample corrections for the standard errors were implemented by following the procedure advanced by Windmeijer (2005)
} 
necessary for identification. As mentioned before, valid instruments would become increasingly available in terms of level lagged values starting at lag 2 and including subsequent lags. In the present application, lagged levels for $\triangle \mathrm{NDEB}$ and $\triangle \mathrm{INV}$ are considered for t-2 until t -4 as instruments as well as the constant, time dummies (D94, ..., D98) whenever available, and the regulatory regime variable $\triangle$ REG. Moreover, the parcimonious choice of the lag structure (at most $\mathrm{p}=4$ ) reflected the relatively limited number of time periods. The evidence, in all cases, favored the non-rejection of the null hypothesis of Sargan's test and therefore favors the validity of the chosen instruments.

Moreover, an important diagnostic pertains the assessment of the presence of second order serial correlation in the error term. In fact, even in the absence of serial correlation in the level model, first-differencing would induce first-order serial correlation but not second-order serial correlation. That property is important to guarantee the consistency of the GMM-DIF estimator. In all cases, the corresponding tests are satisfactory and one cannot reject the null hypothesis of the absence of second-order serial correlation.

Even though the analysis of specific coefficients is not the focus of the analysis, it is possible to highlight some salient results. First, the regulatory regime variable as given by $\triangle$ REG does not exert any significant effect as a control in the dynamic relationships that include $\triangle \mathrm{NDEBT}$ and $\triangle \mathrm{INV}$. In principle, could be the case that a leverage effect could be more likely to prevail under rate-of-return regulation where strategic behavior by the regulated firm could more clearly influence rate-setting. However, even under light-handed price-cap regulation the setting of lower productivity offset factor $\mathrm{X}$ could in principle reflect, to some extent, concerns for bankrupcy in leveraged contexts that extrapolate expected productivity gains.

Second, the coefficients of time dummies are often not statiscally significant when considered individually. 
Table 1

Causality analysis INV $\rightarrow$ NDEBT: results from GMM-DIF estimation

\begin{tabular}{|c|c|c|c|c|}
\hline \multirow[t]{2}{*}{ Regressors } & \multicolumn{4}{|c|}{ Dependent variable: $\triangle$ NDEBT } \\
\hline & $\mathbf{p}=\mathbf{1}$ & $p=2$ & $\mathbf{p}=3$ & $\mathbf{p}=4$ \\
\hline Constant & $\begin{array}{c}-25912.9 \\
(0.281) \\
\end{array}$ & $\begin{array}{c}1163.18 \\
(0.973) \\
\end{array}$ & $\begin{array}{c}-34968.6 \\
(0.491) \\
\end{array}$ & $\begin{array}{c}98866.4 \\
(0.057)\end{array}$ \\
\hline$\Delta$ NDEBT $_{-1}$ & $\begin{array}{c}-0.372 \\
(0.000)\end{array}$ & $\begin{array}{c}-0.427 \\
(0.000)\end{array}$ & $\begin{array}{c}-0.501 \\
(0.000)\end{array}$ & $\begin{array}{c}-0.463 \\
(0.000)\end{array}$ \\
\hline$\Delta$ NDEBT $_{-2}$ & - & $\begin{array}{c}-0.136 \\
(0.397)\end{array}$ & $\begin{array}{c}-0.242 \\
(0.308)\end{array}$ & $\begin{array}{c}-0.114 \\
(0.653)\end{array}$ \\
\hline$\Delta$ NDEBT $_{-3}$ & - & - & $\begin{array}{l}-0.086 \\
(0.453)\end{array}$ & $\begin{array}{c}0.095 \\
(0.559)\end{array}$ \\
\hline$\Delta$ NDEBT $_{-4}$ & - & - & - & $\begin{array}{c}-0.351 \\
(0.848)\end{array}$ \\
\hline$\Delta \mathbf{I N V}_{-1}$ & $\begin{array}{c}0.545 \\
(0.008)\end{array}$ & $\begin{array}{c}0.018 \\
(0.951) \\
\end{array}$ & $\begin{array}{l}-6.375 \\
(0.049)\end{array}$ & $\begin{array}{c}-1.268 \\
(0.859)\end{array}$ \\
\hline$\Delta \mathbf{I N V}_{-2}$ & - & $\begin{array}{c}-0.995 \\
(0.000)\end{array}$ & $\begin{array}{c}-3.721 \\
(0.090)\end{array}$ & $\begin{array}{l}-5.008 \\
(0.416)\end{array}$ \\
\hline$\Delta \mathbf{I N V}_{-3}$ & - & - & $\begin{array}{c}0.891 \\
(0.451) \\
\end{array}$ & $\begin{array}{c}0.093 \\
(0.981) \\
\end{array}$ \\
\hline$\Delta \mathbf{I N V}_{-4}$ & - & - & - & $\begin{array}{c}-0.351 \\
(0.848)\end{array}$ \\
\hline$\Delta \mathbf{R E G}$ & $\begin{array}{c}66136.9 \\
(0.407) \\
\end{array}$ & $\begin{array}{c}36362.4 \\
(0.756)\end{array}$ & $\begin{array}{c}7407.37 \\
(0.940) \\
\end{array}$ & $\begin{array}{c}56496.2 \\
(0.688) \\
\end{array}$ \\
\hline D1992 & $\begin{array}{c}20883.5 \\
(0.627)\end{array}$ & - & - & - \\
\hline D1993 & $\begin{array}{c}-22286.6 \\
(0.622)\end{array}$ & $\begin{array}{c}-49262.4 \\
(0.270)\end{array}$ & - & - \\
\hline D1994 & $\begin{array}{l}135734 \\
(0.006) \\
\end{array}$ & $\begin{array}{l}113648 \\
(0.081) \\
\end{array}$ & $\begin{array}{l}126614 \\
(0.121) \\
\end{array}$ & - \\
\hline D1995 & $\begin{array}{c}-52831.6 \\
(0.209)\end{array}$ & $\begin{array}{c}-75322.2 \\
(0.104)\end{array}$ & $\begin{array}{c}-27355.6 \\
(0.601)\end{array}$ & $\begin{array}{c}-162903 \\
(0.089)\end{array}$ \\
\hline D1996 & $\begin{array}{l}106060 \\
(0.009) \\
\end{array}$ & $\begin{array}{c}98412.2 \\
(0.043)\end{array}$ & $\begin{array}{l}134324 \\
(0.074) \\
\end{array}$ & $\begin{array}{c}-27773.4 \\
(0.647)\end{array}$ \\
\hline D1997 & $\begin{array}{c}4682.62 \\
(0.901) \\
\end{array}$ & $\begin{array}{c}-33455.0 \\
(0.458) \\
\end{array}$ & $\begin{array}{c}36031 \\
(0.466) \\
\end{array}$ & $\begin{array}{c}-134501 \\
(0.020) \\
\end{array}$ \\
\hline D1998 & $\begin{array}{c}-71642.9 \\
(0.107) \\
\end{array}$ & $\begin{array}{l}-97187 \\
(0.105) \\
\end{array}$ & $\begin{array}{c}-66548.7 \\
(0.524) \\
\end{array}$ & $\begin{array}{c}-192032 \\
(0.025) \\
\end{array}$ \\
\hline Sargan test & $\begin{aligned} & \chi^{2}(39)= 18.68 \\
&(0.998) \\
&\end{aligned}$ & $\begin{array}{r}\chi^{2}(31)=18.35 \\
(0.991)\end{array}$ & $\begin{array}{r}\chi^{2}(29)=23.50 \\
(0.753)\end{array}$ & $\begin{array}{r}\chi^{2}(21)=15.78 \\
(0.782)\end{array}$ \\
\hline AR(1) test & $\begin{array}{l}-2.389 \\
(0.017) \\
\end{array}$ & $\begin{array}{l}-2.152 \\
(0.031)\end{array}$ & $\begin{array}{l}-1.955 \\
(0.051) \\
\end{array}$ & $\begin{array}{c}15.78 \\
(0.782) \\
\end{array}$ \\
\hline AR(2) test & $\begin{array}{c}-0.924 \\
(0.355)\end{array}$ & $\begin{array}{l}-0.156 \\
(0.876)\end{array}$ & $\begin{array}{c}-0.041 \\
(0.967)\end{array}$ & $\begin{array}{l}-0.227 \\
(0.821)\end{array}$ \\
\hline
\end{tabular}

Note: p-values are indicated in parentheses 
Table 2

Causality analysis NDEBT $\rightarrow$ INV: results from GMM-DIF estimation

\begin{tabular}{|c|c|c|c|c|}
\hline \multirow[t]{2}{*}{ Regressors } & \multicolumn{4}{|c|}{ Dependent variable: $\Delta$ INV } \\
\hline & $p=1$ & $p=2$ & $\mathbf{p}=3$ & $p=4$ \\
\hline Constant & $\begin{array}{l}7187.11 \\
(0.248)\end{array}$ & $\begin{array}{c}999.255 \\
(0.271)\end{array}$ & $\begin{array}{l}214.54 \\
(0.751)\end{array}$ & $\begin{array}{c}-446.521 \\
(0.556)\end{array}$ \\
\hline$\Delta \mathbf{I N V}_{-1}$ & $\begin{array}{l}-0.466 \\
(0.000)\end{array}$ & $\begin{array}{l}-0.622 \\
(0.000)\end{array}$ & $\begin{array}{c}-3.67 \mathrm{E}-04 \\
(0.995)\end{array}$ & $\begin{array}{l}-0.052 \\
(0.581)\end{array}$ \\
\hline$\Delta \mathbf{I N V _ { - 2 }}$ & - & $\begin{array}{l}-0.302 \\
(0.000)\end{array}$ & $\begin{array}{l}-0.007 \\
(0.867)\end{array}$ & $\begin{array}{c}0.014 \\
(0.819)\end{array}$ \\
\hline$\Delta \mathbf{I N V} \mathbf{N}_{-3}$ & - & - & $\begin{array}{l}-0.009 \\
(0.632)\end{array}$ & $\begin{array}{c}-0.004 \\
(0.917)\end{array}$ \\
\hline$\Delta \mathbf{I N V}_{-4}$ & - & - & - & $\begin{array}{l}-0.014 \\
(0.291)\end{array}$ \\
\hline$\Delta$ NDEBT $_{-1}$ & $\begin{array}{c}0.003 \\
(0.125)\end{array}$ & $\begin{array}{c}-0.001 \\
(0.824)\end{array}$ & $\begin{array}{c}0.001 \\
(0.408) \\
\end{array}$ & $\begin{array}{c}0.004 \\
(0.004)\end{array}$ \\
\hline$\Delta$ NDEBT $_{-2}$ & - & $\begin{array}{l}-0.005 \\
(0.420)\end{array}$ & $\begin{array}{c}-5.08 \mathrm{E}-04 \\
(0.814)\end{array}$ & $\begin{array}{c}0.001 \\
(0.619)\end{array}$ \\
\hline$\Delta$ NDEBT $_{-3}$ & - & - & $\begin{array}{c}4.62 \mathrm{E}-04 \\
(0.747)\end{array}$ & $\begin{array}{c}0.002 \\
(0.505) \\
\end{array}$ \\
\hline$\Delta$ NDEBT $_{-4}$ & - & - & - & $\begin{array}{c}0.001 \\
(0.753)\end{array}$ \\
\hline$\Delta \mathbf{R E G}$ & $\begin{array}{c}-6672.62 \\
(0.337) \\
\end{array}$ & $\begin{array}{c}-5137.77 \\
(0.235) \\
\end{array}$ & $\begin{array}{l}1304.72 \\
(0.376) \\
\end{array}$ & $\begin{array}{l}1266.3 \\
(0.447) \\
\end{array}$ \\
\hline D1992 & $\begin{array}{c}-6598.2 \\
(0.252)\end{array}$ & - & - & - \\
\hline D1993 & $\begin{array}{c}-8172.33 \\
(0.313)\end{array}$ & $\begin{array}{c}-341.289 \\
(0.727)\end{array}$ & - & - \\
\hline D1994 & $\begin{array}{c}-7111.28 \\
(0.216) \\
\end{array}$ & $\begin{array}{c}-2255.57 \\
(0.055) \\
\end{array}$ & $\begin{array}{c}-1029.60 \\
(0.242) \\
\end{array}$ & - \\
\hline D1995 & $\begin{array}{c}-4518.52 \\
(0.263) \\
\end{array}$ & $\begin{array}{c}1117.99 \\
(0.603)\end{array}$ & $\begin{array}{c}140.572 \\
(0.885) \\
\end{array}$ & $\begin{array}{c}611.234 \\
(0.484) \\
\end{array}$ \\
\hline D1996 & $\begin{array}{c}-5532.19 \\
(0.361)\end{array}$ & $\begin{array}{c}985.848 \\
(0.551)\end{array}$ & $\begin{array}{c}655.498 \\
(0.562) \\
\end{array}$ & $\begin{array}{l}1344.33 \\
(0.310)\end{array}$ \\
\hline D1997 & $\begin{array}{c}-7102.47 \\
(0.237) \\
\end{array}$ & $\begin{array}{c}-982.458 \\
(0.401) \\
\end{array}$ & $\begin{array}{l}-1219.7 \\
(0.379) \\
\end{array}$ & $\begin{array}{c}-789.462 \\
(0.517) \\
\end{array}$ \\
\hline D1998 & $\begin{array}{c}-6621.28 \\
(0.270) \\
\end{array}$ & $\begin{array}{c}293.021 \\
(0.824) \\
\end{array}$ & $\begin{array}{c}913.786 \\
(0.215) \\
\end{array}$ & $\begin{array}{c}1532.77 \\
(0.024) \\
\end{array}$ \\
\hline Sargan test & $\begin{array}{r}\chi^{2}(39)=17.39 \\
(0.999)\end{array}$ & $\begin{array}{r}\chi^{2}(35)=23.74 \\
(0.926)\end{array}$ & $\begin{array}{r}\chi^{2}(29)=19.45 \\
(0.909)\end{array}$ & $\begin{array}{r}\chi^{2}(21)=18.08 \\
(0.644)\end{array}$ \\
\hline AR(1) test & $\begin{array}{l}-0.6219 \\
(0.534)\end{array}$ & $\begin{array}{c}-1.228 \\
(0.220) \\
\end{array}$ & $\begin{array}{l}-1.438 \\
(0.150)\end{array}$ & $\begin{array}{c}-1.352 \\
(0.176)\end{array}$ \\
\hline AR(2) test & $\begin{array}{l}-1.067 \\
(0.286)\end{array}$ & $\begin{array}{l}-0.923 \\
(0.356)\end{array}$ & $\begin{array}{c}0.067 \\
(0.946)\end{array}$ & $\begin{array}{l}-0.406 \\
(0.685)\end{array}$ \\
\hline
\end{tabular}

Note: p-values are indicated in parentheses

Next, I consider joint significant tests that will enable in the end conclusions in terms of Granger causality. The corresponding test are presented in table 3. 
Table 3

Joint significance tests

\begin{tabular}{|c|c|c|c|c|}
\hline \multirow{2}{*}{ Test } & \multicolumn{4}{|c|}{ Dependent variable: $\triangle$ NDEBT } \\
\hline & $p=1$ & $p=2$ & $p=3$ & $\mathrm{p}=4$ \\
\hline $\begin{array}{l}\text { overall } \\
\text { significance }\end{array}$ & $\begin{array}{c}47.21 \\
(0.000)\end{array}$ & $\begin{array}{c}156.8 \\
(0.000)\end{array}$ & $\begin{array}{c}1760 \\
(0.000)\end{array}$ & $\begin{array}{c}1516 \\
(0.000)\end{array}$ \\
\hline time dummies & $\begin{array}{c}34.91 \\
(0.000)\end{array}$ & $\begin{array}{l}16.21 \\
(0.023)\end{array}$ & $\begin{array}{c}13.77 \\
(0.032)\end{array}$ & $\begin{array}{c}12.52 \\
(0.028)\end{array}$ \\
\hline $\operatorname{lag} p$ & $\begin{array}{l}46.893 \\
(0.000) \\
\end{array}$ & $\begin{array}{r}14.9373 \\
(0.001) \\
\end{array}$ & $\begin{array}{c}1.064 \\
(0.588) \\
\end{array}$ & $\begin{array}{c}3.652 \\
(0.161) \\
\end{array}$ \\
\hline INV $\rightarrow$ NDEBT & $\begin{array}{l}7.151 \\
(0.008)\end{array}$ & $\begin{array}{l}55.898 \\
(0.000)\end{array}$ & $\begin{array}{l}165.324 \\
(0.000)\end{array}$ & $\begin{array}{l}418.729 \\
(0.000)\end{array}$ \\
\hline \multirow{2}{*}{ Test } & \multicolumn{4}{|c|}{ Dependent variable: $\Delta \mathrm{INV}$} \\
\hline & $\mathbf{p}=1$ & $\mathbf{p}=2$ & $p=3$ & $\mathrm{p}=4$ \\
\hline $\begin{array}{l}\text { overall } \\
\text { significance }\end{array}$ & 1.519E04 (0.000) & 4.476E04 (0.000) & $\begin{array}{c}80.49 \\
(0.000)\end{array}$ & $\begin{array}{c}73.87 \\
(0.000)\end{array}$ \\
\hline time dummies & $\begin{array}{c}26.43 \\
(0.001) \\
\end{array}$ & $\begin{array}{c}12.51 \\
(0.085)\end{array}$ & $\begin{array}{c}10.21 \\
(0.116)\end{array}$ & $\begin{array}{c}10.08 \\
(0.073) \\
\end{array}$ \\
\hline $\operatorname{lag} p$ & $\begin{array}{r}2072.85 \\
(0.000) \\
\end{array}$ & $\begin{array}{l}9757.75 \\
(0.000)\end{array}$ & $\begin{array}{c}0.391 \\
(0.822) \\
\end{array}$ & $\begin{array}{c}3.273 \\
(0.195) \\
\end{array}$ \\
\hline NDEBT $\rightarrow$ INV & $\begin{array}{l}2.365 \\
(0.124) \\
\end{array}$ & $\begin{array}{l}3.298 \\
(0.192) \\
\end{array}$ & $\begin{array}{c}1.925 \\
(0.5882) \\
\end{array}$ & $\begin{array}{l}13.507 \\
(0.009) \\
\end{array}$ \\
\hline
\end{tabular}

Note: p-values are indicated in parentheses

The inspection of table 3 indicates that in all cases overall joint significance prevails for the totality of coefficients (excluding the constant). Moreover, joint significance prevails for the time dummies in the majority of the cases,

Next, one needs to select a configuration for the lag structure before considering the causality tests. The joint significance tests of the coefficients of the p-th lag favors $\mathrm{p}=2$ for regressions in both directions. However, the results are robust for different lags. Essentially one observes that past values of $\triangle \mathrm{INV}$ are significant in explaining $\triangle$ NDEBT whereas the reverse is not the case. The evidence thus indicate a unidirectional causality from INV to NDEBT and therefore is in part consistent with a leverage effect and with the notion that the size of the firm's investment project can impose a restriction on the amount of new debt.

\section{Final Comments}

The paper aimed at investigating the relationship between regulation and the capital structure of the regulated firm. Causality tests were carried out between new debt (NBEDT) as proxied by change in long-term debt and investment in physical capital (INV) as proxied by change in gross communication plant. The evidence indicated a uni-directional causality from INV to NDEBT and therefore is consistent with a possibly relevant leverage effect. The result is sustained whatever regulatory regime prevails at the state level. It appears that even though traditional rate-of-return regulation regimes are more strict in their controls than more flexible regimes. The paper focused on the change in debt but it would also be interesting to investigate the issue of new stock, though the related data is not readily available.

The paper aimed at an initial empirical investigation of the topic but an ambitious and timely project would be the structural modelling that explicitly considers the role of asymmetric information. Empirical studies are still scarce and include, for example, Wolak (1994) and Gagnepain and Ivaldi (2002). However, technologically dynamic 
sectors like telecommunications place an important challenge and structural investigations on the relationship between regulation and capital structure are still absent in the literature. Clearly it is not trivial to empirically disentangle leverage and signalling effects in terms of a sound and meaningful theoretical framework.

\section{References}

Abel, J.R., Clements, M.E. (1998) “A time-series and cross-sectional classification of state regulatory regimes adopted for local exchange carriers: divestiture to present (1984-1998)”, National Regulatory Research Institute 98-25

Ai, C., Sappington, D.E.M. (2002) "The impact of state incentive regulation on the US telecommunications industry”, Journal of Regulatory Economics 22, 133-160

Arellano, M., Bond, S. (1991) "Some tests of specification for panel data: Monte Carlo evidence and an application to employment equations", Review of Economic Studies 58, 277-297

Banerjee, A. (2003) "Does incentive regulation "cause”' degradation of retail telephone service quality?”, Information Economics and Policy 15, 243-269.

Bradley, M., Jarrel, G.A., Kim, E.H. (1984) “On the existence of an optimal capital structure: theory and evidence”, Journal of Finance 39, 857-878

Baltagi, B. H. (2001), Econometric Analysis of Panel Data, New York: John Wiley \& Sons

Banks, J.S. (1992) "Monopoly piecing and regulatory insight”, Journal of Economics and Management Strategy 1, 203-234

Besanko, D., Spulber, D.F. (1992) "Sequential equilibrium investment by regulated firms”, RAND Journal of Economics 23, 153-170

Bond, S. (2002) "Dynamic panel data models: a guide to micro data methods and practice”, Portuguese Economic Journal 1, 141-162

Bortolotti, B., Cambini, C., Rondi, L., Spiegel, U. (2008), Capital Structure and Regulation: Do Ownership and Regulatory Independence Matter?, CEPR Discussion Paper No. 7100

Gagnepain, P., Ivaldi, M. (2002) "Incentive regulatory policies: the case of public transit systems in France”, RAND Journal of Economics 33, 605-629

Granger, C.W.J. (1969) "Investigating causal relations by econometric models and cross-spectral methods”, Econometrica 37, 424-438

Kridel, D.J., Sappington, D.E.M., Weisman, D.L. (1996) "The effects of incentive regulation in the telecommunications industry: a survey", Journal of Regulatory Economics 9, 269-306

Majumdar, S. (1997) "Incentive regulation and productive efficiency in the US

telecommunications industry”, Journal of Business 70, 547-576.

Phillips, C.F. (1988) The Regulation of Public Utilities: Theory and Practice, Arlington, V.A.: Public Utilities Report Inc., $2^{\text {nd }}$ ed.

Resende, M. (1999) "Productivity growth and regulation in U.S. local telephony”,

Information Economics and Policy 11, 23-44

Resende, M., Façanha, L.O. (2005) "Price cap regulation and service-quality in telecommunications: an empirical study”, Information Economics and Policy 17, 1-12 Sappington, D.E.M. (2002), Price regulation, In M. Cave, S. Majumdar and I. Vogelsang (eds.), Handbook of Telecommunications Economics, Amsterdam: Elsevier Science Publishers, 225-293

Spiegel, Y. (1994) "The capital structure and investment of regulated firms under alternative regulatory regimes”, Journal of Regulatory Economics 6, 297-319

Spiegel, Y. (1996) "The choice of technology and capital structure under rate regulation”, International Journal of Industrial Organization 15, 191-216 
Spiegel, Y., Spulber, D.F. (1994) “The capital structure of a regulated firm”, RAND Journal of Economics 25, 424-440

Spiegel, Y. , Spulber, D.F. (1997) “Capital structure with countervailing incentives”, RAND Journal of Economics, 28, 1-24

Uri, N., (2001) "The effect of incentive regulation on productive efficiency in telecommunications”, Journal of Policy Modeling 23, 825-846

Windmeijer, F. (2005) "A finite sample correction for the variance of linear two-step GMM estimators”, Journal of Econometrics 126, 25-51

Wolak, F. (1994) "An econometric analysis of the asymmetric information, regulatorutility interaction”, Annales d'Economie et de Statistique 34, 13-69

\section{Appendix 1}

\section{List of local exchange carriers-LECs}

1) Illinois Bell Telephone Company

2) Indiana Bell Telephone Company

3 )Michigan Bell Telephone Company

4) Ohio Bell Telephone Company

5) Wisconsin Bell Inc.

6) Carolina Telephone and Telegraph Company

7) Central Telephone Company of Florida

8) Verizon Washington D.C. Inc.

9) Verizon Maryland

10) Verizon Virginia

11) Verizon West Virginia

12) Verizon Delaware

13) Verizon Pennsylvania

14) Verizon New Jersey

15) Verizon New England

16) Verizon New York

17) Nevada Bell

18) Pacific Bell

19) Southwestern Bell Telephone Company

20) Cincinatti Bell Telephone Compoany

21) Southern New England Telephone Company

22) Central Telephone Company of Virginia

23) Verizon California Inc.

24) Verizon Florida Inc.

25) Verizon Hawaii Inc.

26) Verizon North Inc.

27) Verizon Northwest Inc.

28) Verizon Southwest Inc.

29) United Telephone Company of Indiana

30) United Telephone Company of Ohio

31) United Telephone Company of Pennsylvania 

